\title{
Seismic tomography of the Arctic region: Inferences for the thermal structure and evolution of the lithosphere
}

\author{
Sergei Lebedev ${ }^{1 *}$, Andrew J. Schaeffer ${ }^{2}$, Javier Fullea ${ }^{1} \&$ Victoria Pease ${ }^{3}$ \\ ${ }^{1}$ Geophysics Section, School of Cosmic Physics, Dublin Institute for Advanced Studies, 5 Merron Sq., \\ Dublin 2, Ireland (e-mail: sergei@cp.dias.ie) \\ ${ }^{2}$ Department of Earth and Environmental Sciences, University of Ottawa, Room 15032, FSS Hall, \\ 120 University Pr, Ottawa, Canada \\ ${ }^{3}$ Department of Geological Sciences, Stockholm University, 106 91, Sweden \\ *Correspondence (sergei@cp.dias.ie)
}

\begin{abstract}
New waveform tomography with very large datasets yields improved resolution in the upper mantle of the Arctic region. Computational petrology enables quantitative estimation of temperature from tomography in the lithosphere-asthenosphere depth range. Most boundaries of the mantle roots of cratons in the Arctic follow their geological boundaries at the surface. The roots of the Greenland and North American Cratons are separated by the Baffin Bay and a thin-lithosphere corridor through the middle of the Canadian Arctic Archipelago; the southern archipelago is a part of the North American Craton. The mantle root of the cratonic block beneath northern Greenland may extend westward as far as central Ellesmere Island. The Barents and Kara Sea show high velocities indicative of thick lithosphere, similar to cratons. Locations of intraplate basaltic volcanism of the High Arctic Large Igneous Province are all on thin, non-cratonic lithosphere. The lithosphere beneath the central part of the Siberian Traps is warmer and thinner than elsewhere beneath the Siberian Craton; this indicates the likely location of the lithospheric erosion associated with the Large-Igneous-Province volcanism. A corridor of relatively low seismic velocities cuts east-west across central Greenland and appears to delineate the track of the Iceland Hotspot.
\end{abstract}

Keywords: Arctic, tomography, lithosphere, mantle temperature, orogeny

Supplementary material: figures with comparisons of different tomographic models at 50 and $200 \mathrm{~km}$ depths are available at...

The Arctic region comprises lithospheric blocks with very different properties and very different tectonic history (Fig. 1). The continental units range in age from Archean cratons to Phanerozoic orogens (Pease et al. 2014). The deep-water High Arctic includes the Canada Basin, probably over $100 \mathrm{~m}$.y. old, and the younger Eurasia Basin associated with modern spreading along the Gakkel Ridge (Herron et al. 1974). The intraplate basaltic volcanism of the Cretaceous High Arctic Large Igneous Province (HALIP) (Tarduno 1998; Saumur et al. 2016) has disrupted and modified pre-existing lithosphere across a broad area. The Cenozoic opening of the adjacent North Atlantic was accompanied by volcanism at and near the Iceland 
Hotspot, with the hotspot activity likely to have affected the thermal evolution of both the oceanic lithosphere and the continental margins of the North Atlantic (e.g., White and Lovell 1996).

Understanding the structure and evolution of the different tectonic units-and of their interrelationships within the Arctic region as a whole-requires understanding the structure and evolution of the entire lithospheric plates, from the crust to the lithospheric mantle. Two of the key parameters that determine the physical nature and mechanical behaviour of the lithosphere are its temperature and thickness. The two are closely related: the bottom of the thermal lithosphere (the lithosphereasthenosphere boundary) is defined by the depth near which the steep, conductive geotherm that characterises the lithosphere meets the mantle adiabat that characterises the convecting asthenosphere below (Fig. 2).

Both the temperature and strength of the lithosphere also depend on the thickness and properties of the crust. Radiogenic heat production in thick continental crust makes continental lithosphere warmer than oceanic lithosphere of the same thickness, with the latter producing little heat within its thin basaltic crust (Fig. 2). Colder lithosphere is generally stiffer, although the mechanical behaviour of the lithosphere also depends on the strength layering within it (e.g., Burov \& Watts 2006).

Because the lithosphere is cooled at the Earth's surface, it will tend to grow in thickness until its lower portion becomes unstable and delaminates, sinking into the underlying mantle. The thickness of the lithosphere thus reaches a maximum, and this maximum is determined by the composition of the lithospheric mantle. The lithosphere beneath Archean cratons is compositionally buoyant due to its depletion in basaltic components (e.g., Jordan 1975; 1988), so that it has a greater thickness than lithosphere elsewhere (e.g., Artemieva 2006). In seismic tomography models (which map variations in temperature-dependent seismic velocities), the cold, thick lithospheres of cratons around the world are manifest as prominent high-velocity anomalies, seen down to 200-250 km depths (e.g., French et al. 2013; Schaeffer and Lebedev 2015; Debayle et al. 2016).

Phanerozoic mantle lithosphere, in contrast, is less depleted and lacks the compositional buoyancy to grow as thick as the lithosphere of Archean cratons. The maximum thickness of Phanerozoic lithosphere has been estimated at around $150 \mathrm{~km}$ (Poudjom Djomani et al., 2001), with a more typical thickness probably around $100 \mathrm{~km}$. Tomographic models show seismic velocities within Phanerozoic lithosphere that are substantially lower than within the cratonic Archean lithosphere, reflecting much higher temperatures within the former.

Oceanic lithosphere appears to cool and thicken largely monotonically, from its origin at a mid-ocean ridge to its subduction (e.g., Maggi et al. 2006; Schaeffer and Lebedev, 2013; Burgos et al. 2014). The cooling can be interrupted by the plate passing over a mantle hotspot, which will re-heat the lithosphere; subsequently, the plate will resume its cooling and thickening. The flattening of the bathymetry of old (>80 Myr) oceans and the apparent independence of heat flow on their lithospheric age have suggested that the thickness of the oceanic lithosphere may reach a maximum when the seafloor is c. $80 \mathrm{Ma}$ (the "plate model", e.g., Stein and Stein 1992; 2015). Interestingly, seismic velocity structure and azimuthal anisotropy show evidence for the lithosphere continuing to grow in thickness 
along the isotherms of the "half-space cooling model" with age (Davis and Lister, 1974), without reaching a maximum (Becker et al. 2014; Schaeffer et al. 2016a).

Generally, the lithospheric temperature and thickness beneath both continents and oceans reflect the age and the evolution of the lithosphere. A craton, a Phanerozoic platform, and an active orogen will all have distinctly different lithospheric temperatures and thicknesses, and so will an old and a young part of an ocean basin. Lithospheric temperatures can, thus, inform us of key properties of tectonic terranes and of the locations of the boundaries between them.

Lateral variations of temperature within the mantle lithosphere can be inferred from seismic velocities. Apart from temperature, seismic velocities also depend on the composition of the rock and on the presence of water or partial melt within it. The effect of compositional variations in the mantle, however, is much smaller than that of temperature: it can account for less than $1 \%$ of shear-wave speed variations (e.g. Deschamps et al., 2002; Schutt and Lesher, 2006), whereas the positive shear-wave speed anomalies beneath cratons, for example, reach 8-10\% above the global averages (Lebedev et al. 2009). At the opposite end of the range of seismic-velocity variations, they can be over $10 \%$ below the average beneath mid-ocean ridges and intraplate volcanic areas (e.g., Schaeffer and Lebedev 2015). In these locations, the lithosphere is thin and hot, and seismic velocities are lowered further by partial melting, in particular in the top $100 \mathrm{~km}$ of the mantle. In the back-arc regions of subduction zones, partial melting is enhanced by the water released from the subducting crust into the mantle.

Shear-wave speed anomalies mapped by tomography can thus offer an immediate qualitative estimate for temperature heterogeneity of the lithosphere. In order to calculate temperature from seismic velocity at a given depth quantitatively, sensitivity of elastic and anelastic properties of realistic rock compositions needs to be evaluated (e.g., Karato, 1993; Sobolev et al., 1996; Goes et al., 2000; Cammarano et al., 2003). Recently developed methods of computational petrological modelling (e.g., Connoly 2005; Afonso et al., 2008; Fullea et al., 2009) enable fast and accurate calculation of density, seismic velocities, attenuation, and other properties of the rock as a function of its composition, temperature and pressure based on extensive thermodynamic databases, and offer a self-consistent framework for relating seismic and other data to the physical properties of the entire lithosphere.

In this paper, we use new waveform tomography of the Arctic to analyse the variations of seismic velocities across the region. The seismic-velocity heterogeneity resolved by the new tomographic model presents abundant evidence on the nature of the various tectonic blocks in the region, the location of the boundaries between them, and the dynamic processes at depth. We also use computational petrology to calculate lateral variations in the temperature of the lithosphere and estimate lithospheric geotherms beneath selected locations in the High Arctic.

\section{Seismic tomography}

Thanks to the explosive recent growth of global and regional seismic networks, increasingly detailed models of the lithosphere and underlying upper mantle are now becoming possible, at scales from 
regional to global. In order to take advantage of the resolving power of the very large available datasets, we must apply methods that extract highly complete structural information from each seismogram and that are automated, so that all relevant data can be processed.

\section{Waveform Tomography}

Waveform tomography is an effective approach for imaging the entire crust and upper mantle at a regional or global scale (e.g., Nolet 1990; Lebedev et al. 1997; Lebedev \& Nolet 2003; Legendre et al. 2012; Schaeffer \& Lebedev 2013, 2014). We invert seismic waveforms that include the fundamentalmode surface waves (which travel along the surface of the Earth and sense different depth ranges depending on their periods) and $S$ and multiple $S$ waves (which dive deeper into the mantle and have complementary depth sensitivities that depend on the source-station distance and the order of the multiple). Regional $S$ and multiple $S$ waves are often triplicated and, also, interfere with each other and with the fundamental mode on the seismogram. By inverting entire seismic waveforms, we can extract information simultaneously from all these waves without the need to separate their arrivals.

The Automated Multimode Inversion of surface and S-wave forms (AMI; Lebedev et al. 2005) performs automated, accurate processing of large quantities of broadband seismograms. Each successful waveform inversion produces a set of linear equations with uncorrelated uncertainties (Nolet 1990) that describe one-dimensional (1D) perturbations in elastic structure within a finite-width sensitivity volume between the earthquake and the station. The perturbations are with respect to a three-dimensional (3D) reference model, including, in particular, a realistic crust (Lebedev \& van der Hilst 2008). All of the linear equations are then solved together for 3D perturbations in isotropic $S$ and $P$ velocity with respect to the 3D reference model, as well as for 180-degree-periodic azimuthal anisotropy of $S$ velocity. The broad period range of the fundamental mode surface waves (10-400 s) and the complementary sensitivities of the regional $S$ and multiple $S$ waves provide resolution from the crust down to the deep upper mantle, including the entire lithosphere-asthenosphere depth range.

Our new tomographic model, AMISvArc, is a global, shear-wave speed model of the upper mantle and crust, constructed using the same waveform tomography methods and data handling approaches as the recently published SL2013sv, SV2013NA and SL2016SvA (Schaeffer \& Lebedev, 2013, 2014, 2015; Schaeffer et al. 2016a), but incorporating additional data, particularly in and around the Arctic region (Fig. 3). In the High Arctic, there are no stations in its central, sea-covered part, but because we use surface and regional body waves traversing between the various sources and stations, we have dense coverage across the entire region. A specific technical description and validation of the tomographic model are presented elsewhere (Schaeffer et al. 2016b); a description of the waveform tomography methods can be found in Lebedev et al. (2005) and Lebedev \& van der Hilst (2008). In the following, we focus on the inferences on the lithospheric structure of the Arctic region offered by the model.

\section{S-wave speed variations in the lithosphere and asthenosphere}


Figure 4 shows map views of our model at depths in the shallow upper mantle. At $30-60 \mathrm{~km}$, a dominant feature that stands out in the High Arctic is the cold lithosphere of the Canada Basin. S-wave speeds

151 here are similar to those within old (>100 m.y.) oceanic lithosphere around the world (Schaeffer \&

152 Lebedev 2015). They are substantially higher than those beneath the younger Eurasia Basin (where the

153 lithosphere is thinner and warmer) and also higher than beneath the continental margins of the Canada

154 Basin (where the uppermost mantle is likely to be warmer due to the radiogenic heating within the

155 continental crust).

156 At 80-110 km depth, cratons are the dominant high-velocity anomalies. In most cases, the deep 157 boundaries of the cratonic roots in the mantle closely follow the boundaries mapped at the surface. A

158 few significant exceptions to this are discussed below.

159 At $150 \mathrm{~km}$ and below (Fig. 5), there is no longer a visible contrast in seismic velocities between the central Canada Basin and the Eurasia Basin. Instead, a continuous low-velocity anomaly stretches from one basin to the other-an image of the warm asthenosphere beneath the High Arctic. This low-velocity anomaly is significantly smaller in amplitude than the one beneath the North Atlantic in the vicinity of the Iceland Hotspot, where the extremely low velocities indicate partial melting in the mantle.

In the SE corner of the Canada Basin, a high-velocity anomaly stands out at depths greater than $100 \mathrm{~km}$, adjacent to the thick, cold lithosphere of the Mackenzie Craton, the NW extremity of the North American Craton (Schaeffer \& Lebedev 2014). The anomaly is seen beneath the Beaufort Sea and also extends to the west and to the east of it (Fig. 5, 150-330 km).

Figures 6 and 7 show a comparison of recent global upper-mantle and whole-mantle models at 100 and $150 \mathrm{~km}$ depths (see also the figures in the Supplementary material for 50 and $200 \mathrm{~km}$ depth comparisons). Each model is plotted with respect to its own global mean at the depth. (The reference model used in tomographic inversions will normally be somewhat different from the eventual global mean of the model, hence the slight difference in the appearance of AMISvArc in Figs. 4 and 5, where it is plotted with respect to its reference model, and in Figs. 6 and 7, where it is plotted with respect to its global mean.)

All the tomographic models were constrained by datasets that included surface waves, particularly sensitive to $S$-wave speed variations in the lithospheric depth range (Bartzsch et al. 2011; Lebedev et al. 2013). Some of the models also included waveforms of regional $S$ and multiple $S$ waves (including our AMISvArc, top left), surface-wave higher-mode measurements, or teleseismic body-wave arrival times.

181 The quantity of data and station coverage vary substantially between the models (with AMISvArc using 182 the most complete current station coverage in and around the Arctic, Fig. 3), and so do inversion 183 schemes. 
The comparison shows which features are consistently mapped by all the models. These include, for example, the mantle roots of the North American, East European and Siberian Cratons, where the thick, cold lithosphere is characterized by high seismic velocities, seen as dark blue and purple colours (Figs. 6, 7). All the models also show the warm High-Arctic asthenosphere and the hot asthenosphere beneath Iceland.

As we go to smaller spatial scales, the models differ. For example, all the models show a relatively thick lithosphere beneath the Barents Sea, but the distributions of the high-velocity anomalies beneath the sea, laterally and with depth, varies from one model to another (see also the Supplementary material figures). The $V s$ distribution here is also different in published regional surface-wave tomography (Levshin et al. 2007). The Barents Sea presents a challenge because of the very thick layer of sediments across much of it, not accounted for in sufficient detail in global reference crustal models. Fine-scale, regional crustal models will need to be incorporated into tomography with large, Arctic-scale datasets in order to resolve the smaller-scale lithospheric structure variations beneath and around the Barents Sea.

Some models (Savani, S40RTS) are very smooth, and others include smaller-scale structure. For the most part, the models are mutually consistent at the large scales. As we go to the finer scale structure-seen, in particular, in AMISCArc-many regional-scale features are seen clearer and present clearer evidence on the regional structure and evolution of the lithosphere. Examples of such regional-scale features include the corridor of relatively low velocities separating the cratonic roots of Greenland and North American Cratons, the low-velocity corridor cutting east-west across central Greenland, and the thinning of the lithosphere beneath the central part of the Siberian Traps.

\section{Mapping lithospheric temperature}

For a rock of a given composition at a given pressure $(P)$ and temperature $(T)$, we can compute the shear-wave speed within it ( $V s$ ), attenuation (important because it affects the $V s-T$ relationship) and other properties (e.g., Connolly 2005, Fullea et al. 2012). A Vs distribution such as in Figs. 4 and 5 can, therefore, be inverted for a distribution of temperature if we assume some reasonable, representative compositions for the mantle lithosphere and asthenosphere. If the composition and the rock properties that control attenuation are fixed, then there is a non-linear but unique, one-to-one relationship between $T$ and $V s$. The $V s-T$ inversion can thus be recast as a simple conversion by pre-computing $V s$ for the entire relevant ranges of temperatures, pressures and compositions.

The solutions of the tomographic inverse problem are non-unique: many different models can fit the data equally well. Specifically, our data constrain tightly the values of $V s$ in relatively broad depth ranges but constrain poorly small-scale radial $V s$ variations. Thus, instead of converting $V s$ values at a given single depth to $T$ at this depth, we determine an average $T$ over a depth range. The depth range needs to be sufficiently broad for the average temperature values within it to be robust. It also needs to capture relevant lithospheric property variations across the region. (Alternatively, one could reduce the non-uniqueness of seismic models in the course of their construction, either by introducing petrological constraints into the inversions or by formulating them as thermodynamic inversions from the beginning 
(e.g., Khan et al. 2009, 2011; Fullea et al. 2012; Afonso et al. 2013). Development of thermodynamic inversion methods for large waveform datasets is the subject of current work.)

Figure 8 shows the average temperature in the $80-150 \mathrm{~km}$ depth range. It is determined as an average of the temperature values computed from Vs (Figs. 4, 5) at each depth within the range. Composition of the upper mantle at a point is assumed to fall into one of the three lithospheric compositional domains, corresponding to tectonothermal ages: Phanerozoic, Proterozoic and Archean. The domains are defined geographically by means of lithospheric regionalization based on our tomographic model (see Schaeffer \& Lebedev 2015; Schaeffer et al. 2016b). A representative composition has been assigned to each domain, based on global average compositions from xenoliths and peridotite massifs (Griffin et al. 2009). Radially, mantle composition varies from that of a lithospheric type (any of the three mentioned before) to a typical sub-lithospheric, pristine upper mantle composition (PUM, McDonough \& Sun 1995) (Table 1). For composition only, an average lithospheric thickness is assumed for each of the three compositional domains. In Phanerozoic and Proterozoic terranes the depth to the base of the layer with the lithospheric composition is set to $120 \mathrm{~km}$. In cratons the composition is "Archaean" from the base of the crust down to $120 \mathrm{~km}$, and "Proterozoic" from $120 \mathrm{~km}$ down to $200 \mathrm{~km}$ depth.

The $V s-T$ inversion is based on the thermodynamically self-consistent temperature-pressure tables (for each of the mantle compositions in Table 1) containing $V s$ values pre-calculated using the computational petrology software package Perple_X (Connolly 2005). Vs values are corrected to account for the effect of attenuation. We compute anelasticity as a pressure-temperature-dependent correction to the anharmonic output velocities from Perple_X (e.g., Afonso et al. 2005; Karato 1993; Minster \& Anderson 1981). The values for grain size and activation volume on the anelasticity correction applied here are taken from Fullea et al. (2012).

White areas in Figure 8 show locations where partial melting is likely to occur at least at some of the depths in the 80-150 km range. Partial melting is inferred if the temperature obtained from the $V \mathrm{~s}$ inversion exceeds the mantle peridotite dry solidus (Katz et al. 2003) at the corresponding pressure.

A useful reference for interpretation of Figure 8 is given by steady-state geotherms, computed as described in the following section. A $260-\mathrm{km}$ thick cratonic lithosphere, for example, has an average temperature within the $80-150 \mathrm{~km}$ depth range of $740^{\circ} \mathrm{C}$. For a continent with a $100-\mathrm{km}$ thick lithosphere (Fig. 2), the computed average temperature is $1277^{\circ} \mathrm{C}$.

\section{Lithospheric geotherms}

We now use the integrated geophysical-petrological software LitMod (Afonso et al. 2008, Fullea et al. 2009) in order to compute the vertical profiles of temperature and density. The lithospheric geotherm is computed under the assumption of steady-state heat transfer in the lithospheric mantle, considering a P-T-dependent thermal conductivity in the mantle and prescribed thermal parameters in the crust (Table 2). In the convecting sub-lithospheric mantle, the geotherm is given by an adiabatic temperature gradient. A transitional buffer layer is located just beneath the bottom of the lithosphere, connecting 
the lithosphere and the convecting sub-lithospheric mantle. This transitional buffer layer is characterized by a continuous linear super adiabatic gradient (i.e., heat transfer is controlled by both conduction and convection, see Fullea et al. (2009) for details). Stable mineral assemblages in the mantle are calculated using a Gibbs free energy minimization, as described by Connolly (2005). The composition is defined within the major oxide system NCFMAS (Na2O-CaO-FeO-MgO-Al2O3-SiO2). All the stable assemblages are computed using a modified and augmented version of the Holland and Powell's (1998) thermodynamic database (Afonso \& Zlotnik, 2011). The density in the mantle is determined according to the elastic moduli and density of each end-member mineral as described by Connolly \& Kerrick (2002) and Afonso et al. (2008).

The calculations are for the entire lithospheric column and, therefore, also produce values for the isostatic topography, gravity, surface heat flow and other observables (e.g., Fullea et al. 2012). The oceanic models in Figure 2 show a 5.5 km seafloor depth for the "old ocean" with a dense, 100-km thick lithosphere, and a $2 \mathrm{~km}$ seafloor depth for the "young ocean" with a 60-km thick lithosphere and a 4-km thick layer of sediment. The latter model was designed to be similar to that of the Nansen Basin, the southern half of the slowly opening Eurasia Basin adjacent to Eurasia's continental margin.

In Figure 9, we compare the profile of the central Canada Basin with those of a non-cratonic continent (100-km thick lithosphere) and a hypothetical profile for the Beaufort Sea. For the central Canada Basin, a 1D model with a steady-state geotherm and a 100-120 km lithospheric thickness can fit both the $V \mathrm{~s}$ values from our tomographic model and the observed bathymetry. For the SE part of the basin (the Beaufort Sea), in contrast, the observations are difficult to fit with a steady-state 1D model. Seismic velocities here are relatively low in the uppermost mantle (similar to those in a Phanerozoic continental region) but relatively high at 100-200 km depth and even deeper. We attempted to construct a 1D physical model that could reproduce these $V s$ variations, while keeping the bathymetry consistent with observations. A model with a 120-km thick lithosphere and a thick layer of sediments with high heat production goes some way towards explaining the relatively low temperatures in the uppermost mantle and relatively high temperatures at greater depths, but it cannot quite match the seismic velocity variations. This suggests that the high velocities at depths greater than $100 \mathrm{~km}$ may be due to the cooling of the upper mantle by the adjacent McKenzie Craton, the NW extremity of the North American Craton (Schaeffer \& Lebedev 2014). The three-dimensionality of the thermal regime is why 1D steadystate models are insufficient to explain the Vs values beneath the Beaufort Sea.

\section{The Arctic lithospheric structure: A brief overview}

The seismic-velocity and thermal structure of the Arctic upper mantle offers abundant evidence on the architecture and evolution of the lithosphere across the region. In the following, we highlight a few selected, robust observations, with a bias for more unexpected-or less well-understood-features and for more provocative inferences. 
297 The seismic-velocity and thermal structure of the Canada Basin lithosphere is similar to that of old oceans. The origin of the basin is debated, with end-member models invoking normal sea-floor spreading, stretching of continental crust, and exhumation and serpentinization of the upper mantle; all three mechanisms may have contributed to the formation of the basin at different locations and different times (Pease et al. 2014; Chian et al. 2016). Our 1D lithospheric-scale physical modelling shows that the inferred temperature within the lithosphere, bathymetry of the basin, and the thickness of its sedimentary cover (Jakobsson et al. 2012; Petrov et al. 2016) are consistent with it having a normaloceanic, basaltic crystalline crust with a thickness of around $7 \mathrm{~km}$. On the basis of the 1D modelling, we cannot rule out, however, that such crust could have been formed by a mechanism other than normal seafloor spreading. Regarding the age of the lithosphere, the temperature profile inferred from the high seismic velocities within it indicates that it has been cooling for over $100 \mathrm{Ma}$.

Eurasia Basin

310

311

312

313

The younger and narrower Eurasia Basin shows lower seismic velocities and higher temperatures, compared to the Canada Basin. In contrast to the Mid-Atlantic Ridge in the North Atlantic, where partial melting is inferred in a broad corridor along its entire length, the ultra-slow spreading Gakkel Ridge in the Eurasia Basin (e.g., Coakley \& Cochran 1998) shows partial melting beneath only a few of its segments, one of them just north of the Fram Strait that separates the North Atlantic and Eurasia Basins.

A continuous low-velocity anomaly extends through the Fram Strait, from the North Atlantic to beneath the adjacent, westernmost portion of the Gakkel Ridge. The extent of this anomaly may indicate how far the hot North Atlantic asthenosphere flows northward. Schmidt-Aursch \& Jokat (2016) used 3D gravity modelling to infer that the separation of Greenland from Svalbard (forming the Fram Strait at chron $\mathrm{C5} / \mathrm{C} 6$ ) led to the inflow of North Atlantic mantle into the western Eurasia Basin, creating a distinct pattern of magmatism along the Gakkel Ridge.

Our tomographic model presents an image of the inflow of hot North Atlantic asthenosphere into the Eurasia Basin. It suggests a major effect of the inflow on the character of the sea-floor spreading: the northern limit of the low-velocity anomaly that we observe (Fig. 4, 80-110 km) is at around $84 \mathrm{~N}$, and this is where a boundary is observed between the Western Volcanic Zone of the Gakkel Ridge to the south, with basalts covering the seafloor and with well-developed magmatic characteristics similar to those of slow-spreading ridges elsewhere, and the Sparsely Magmatic Zone to the north, with little evidence for magmatism and a predominantly peridotitic crust (Thiede et al. 2002; Schlindwein et al. 2007).

\section{Craton-ocean boundaries}

Both the southern half of the Eurasia Basin (the Nansen Basin) and the southern portion of the Canada Basin (the Beaufort Sea) are bordered to the south by thick, cold continental lithospheres. Both 
locations show high-velocity anomalies at $150-200 \mathrm{~km}$ depths, indicating upper mantle that is colder than beneath the rest of the basins further north. This is likely to be due to cooling from the adjacent cold continental lithosphere. The resulting thermal anomaly in the deep upper mantle must have caused an extra amount of subsidence of the basins in the course of their evolution and contributed to the development of their thick sedimentary layers.

\section{Cratons}

The boundaries of the East European and Siberian Cratons, as seen in the mantle (Figs. 4, 5: 110 and 150 $\mathrm{km}$ depths), generally follow their geological boundaries at the surface. To the north, the Barents and Kara Sea also show high velocities indicative of thick lithosphere, similar to that of the cratons.

Seismic-velocity heterogeneity beneath the Baltic Shield reveals pronounced lateral variations of the lithospheric thickness within it. These have been reported previously in a number of studies; different models, however, continue to show substantially different lithospheric-thickness variations (e.g., Bruneton et al. 2004; Artemieva et al. 2006; Weidle \& Maupin 2008; Legendre et al. 2012; Pedersen et al. 2013; this study).

In the NW corner of the North American Craton, our tomography delineates the westward lateral extent of the cratonic lithosphere. The recently identified Mackenzie Craton, unexposed at the surface, forms the northwestern extremity of the North American Craton and extends roughly to the front of the Rockies (Schaeffer \& Lebedev 2014).

The deep cratonic root of Greenland is separated from the root of the North American Craton by tectonic units without a thick cratonic lithosphere. West of central Greenland, the two are separated by the Baffin Bay, with its warmer, thinner oceanic lithosphere. The thin-lithosphere corridor defined by the Baffin Bay stretches further west into the Canadian Arctic Archipelago.

\section{Canadian Arctic Archipelago}

The southern part of the Canadian Arctic Archipelago-the islands to the north of the North America mainland and between North America and Greenland-is clearly a part of the North American Craton, with high seismic velocities indicative of cold, thick lithosphere.

The Sverdrup Basin in the northern part of the archipelago (Fig. 1) is a major Carboniferous to Paleogene depocentre (Stephenson et al. 1987; Embry \& Beauchamp 2008, Midwinter et al. 2016), with sedimentary thicknesses in the 5-15 km range (Petrov et al. 2016). According to our models, the lithosphere is relatively thick in the southern part of the basin and thins to the north; the axis of the basin (Embry \& Beauchamp 2008) coincides roughly with the $1000^{\circ} \mathrm{C}$ isotherm (the transition from green to yellow) in Figure 8. The area to the south of the Sverdrup Basin (comprising the Devon, Somerset, Cornwallis, Bathurst and Melville Islands) shows thinner lithosphere and mostly thin $(<1 \mathrm{~km})$ or absent 
sedimentary cover (Petrov et al. 2016). The subsidence and sedimentation within the Sverdrup Basin are thus likely to reflect the cooling and thickening of the Phanerozoic mantle lithosphere, whereas just south of the Sverdrup Basin, the lithosphere is thin and there has been little subsidence and sedimentation-a causal relationship seen in other parts of the world as well (Meier et al. 2016).

The thin-lithosphere corridor that cuts through the archipelago south of the Sverdrup Basin connects to the Baffin Bay near Devon Island. Here, Burke \& Dewey (1973) postulated a plume-generated, Devon Island triple junction, noting that a junction in this location has also been recognised earlier by Wegener (1929) and Wilson (1963). The three arms of this proposed junction were the Baffin Bay (between Greenland and North America) to the southeast, the Nares Strait (between Greenland and the Ellesmere Island) to the north, and the Lancaster Sound (between Devon and Baffin Islands) to the east. Burke \& Dewey (1973) suggested that the Lancaster Sound arm became inactive before reaching the spreading stage-unlike the Baffin Bay arm, where seafloor spreading has formed the oceanic lithosphere now separating Greenland from North America. The Nares Strait arm, underlain by continental crust (e.g., Altenbernd et al. 2016), was proposed to accommodate left-lateral transform motion.

Our results show pronounced thinning of the lithosphere beneath the corridor between the Sverdrup Basin and the North American Craton. No lithospheric thinning is observed beneath the Nares Strait between Greenland and the Ellesmere Island.

\section{Ellesmere Island}

At $150 \mathrm{~km}$ depth (Fig. 5), the entire southeastern-central part of the Ellesmere Island shows high velocities that appear to form a single anomaly with cratonic northwestern Greenland. Northern Ellesmere Island, in contrast, is underlain by lower velocities, indicative of thinner lithosphere. At 110 km (Fig. 4), seismic velocities beneath the central-southeastern part of the island are also high, but not as high as beneath Greenland. The inferred average lithospheric temperature (Fig. 8) suggests that the central Ellesmere lithosphere is not quite as cold as that of northern Greenland. However, it is as cold as cratonic lithosphere in many locations elsewhere.

While the southeastern-most part of the island is well known to be a part of the Canadian-Greenland Shield, the central part of the island is covered by Cambrian-Devonian shelf deposits (e.g., Saalmann et al. 2005). Our images suggest that the cratonic lithosphere-forming a single lithospheric block with that of northern Greenland-may extend beneath much of the Ellesmere Island. The inferred lateral extent of cratonic lithosphere beneath the island can put limits on where the relative motions between Greenland and (parts of) Ellesmere Island may occur (the "Nares Strait debate", e.g., Dawes \& Kerr 1982; Saalmann et al. 2005). It provides evidence against major displacement along Nares Strait, which is consistent with many Precambrian and Paleozoic structures continuing without offset from Greenland across the Nares Strait to Ellesmere Island (e.g., Dawes et al. 1982; Dawes \& Kerr 1982). 
404 All locations of intraplate basaltic eruptions associated with the HALIP are underlain by relatively thin, non-cratonic lithospheres. This is evidenced by seismic velocities beneath them being much lower than beneath cratons (Fig. 4, 80 and $110 \mathrm{~km}$ depths). For example, northern Ellesmere Island has thin, warm lithosphere with low seismic velocities. It is in this northern part of the island that the Cretaceous alkaline basaltic volcanism associated with HALIP has been identified (Fig. 1). The presence of thick lithosphere beneath the central and southeastern part of the island, as shown by our tomography, is consistent with the volcanism being limited to the northern part of the island. Even if anomalously hot asthenosphere was placed beneath the entire island-or beneath its central part-it would flow towards locations with thinner lithosphere along the lithosphere-asthenosphere boundary and undergo significant partial melting where it reaches relatively shallow depths (Thompson \& Gibson 1991; Morgan \& Morgan 2005; Lebedev et al. 2006), i.e., beneath the northern part of the Ellesmere Island.

\section{Siberian Traps}

The Permo-Triassic Siberian Traps represent one of the largest continental Large Igneous Province (LIP) on Earth, erupted rapidly at around $248 \mathrm{Ma}$ and believed to be located on thick cratonic lithosphere (e.g., Renne \& Basu 1991; Dobretsov et al. 2013). Our model shows that the lithosphere beneath the central part of the LIP is, in fact, warmer and thinner than beneath the surrounding parts of the Siberian Craton.

The thinning of cratonic lithosphere by a hot mantle plume has been modelled recently specifically for the Siberian Traps case, with the model invoking extensive plume melting and erosion of the thick cratonic lithosphere at the time of the emplacement of the traps (Sobolev et al. 2011). Our images map the location where lithospheric thinning associated with the LIP probably took place.

\section{Iceland Plume track across Greenland?}

A corridor of relatively low seismic velocities cuts across central Greenland from west to east (Figs. 4, 5: 110, $150 \mathrm{~km}$; Figs 6, 7: top left), indicating that the lithosphere within this corridor is thinner and warmer than normal cratonic lithosphere. We cannot exclude the possibility that the lithosphere here has been non-cratonic since the assembly of the Greenland landmass. Tectonic boundaries within icecovered Greenland's interior are, unavoidably, somewhat uncertain. It is generally thought, however, that central Greenland-through which the low-velocity corridor cuts-is occupied by the Archean Rae Craton (e.g., St-Onge et al. 2009). The thin-lithosphere corridor may thus be a result of modification of the lithosphere within the craton that post-dated the assembly and stabilization of Greenland. Such modification could occur due to the interaction of the lithosphere with hot sub-lithospheric mantle (Foley 2008). 
The track of the Iceland Hotspot is expected to cross Greenland, although its trajectory across it is uncertain (Lawver \& Müller 1994; Lawver et al. 2002; Mihalffy et al. 2008; Ganerød et al. 2010; Torsvik et al. 2015). Near the eastern coast of Greenland, the thin-lithosphere corridor we observe terminates where Torsvik et al. (2015) put the hotspot at 50-60 Ma. The Cape Hold With Hope-a location of HALIP basaltic volcanism -is just to the north. Just to the south along Greenland's coast, abundant basaltic volcanism occurred at the Blosseville Kyst; this is where the Iceland Hotspot moved (with Greenland as a reference) by $40 \mathrm{Ma}$, according to the reconstruction of Torsvik et al. (2015).

Near Greenland's western coast, the low-velocity corridor we observe is roughly where Lawver \& Müller (1994) placed the hotspot at $70 \mathrm{Ma}-$ also close to the location of significant intraplate volcanism. (The trend of Lawver and Müller's track after $70 \mathrm{Ma}$ is NW-SE, however, compared to the roughly W-E trend of the thin-lithosphere corridor mapped here.)

Previously, Yakovlev et al. (2012) inferred thinned lithosphere beneath parts of central Greenland from their regional, travel-time, $P$-wave tomography and attributed this to the passage of the area over the Iceland Hotspot. In particular, they inferred thin lithosphere roughly beneath the eastern half of the area occupied by the thin-lithosphere corridor seen in our model (see also Petrunin et al. 2013). Steinberger et al. (2015) used global P-wave tomography (Amaru 2007; Bijwaard \& Spakman 2000) and regional waveform tomography (Rickers et al. 2013) to argue that the lithosphere beneath eastern Greenland was thinned by means of thermal and mechanical erosion by the Iceland Plume material underneath.

The thin-lithosphere corridor seen in our models may show the complete extent of Greenland's lithosphere modified by the Iceland Hotspot, as the Greenland landmass moved across it. It thus provides important new evidence on the location of the hotspot track, from the east to the west of Greenland.

\section{Conclusions}

Upper-mantle tomography reveals lateral variations in the temperature and thickness of the lithosphere. Because the variations in seismic velocities reflect primarily variations in temperature, tomographic maps offer a proxy for the lateral variations of temperature in the upper mantle.

New waveform tomography (Schaeffer et al. 2016b; this study) provides improved resolution in the upper mantle of the Arctic, thanks to the highly complete waveform dataset used to construct the model-taking advantage of the recent expansion of broadband seismic networks around the regionand the elaborate waveform inversion and error analysis procedures.

Computational petrology enables self-consistent joint modelling and inversion of various geophysical and geological data. Assuming the composition of the lithosphere and asthenosphere and the parameters controlling anelasticity, seismic tomography models can be converted to thermal models of the upper mantle. A temperature estimate at a point, however, may be biased due to the non- 
uniqueness of the 3D tomographic models. Temperature averages over a depth range represent more robust and reliable temperature estimates. Our new map of the average temperature in the $80-150 \mathrm{~km}$ depth range reveals the lateral thermal heterogeneity in the lithosphere-asthenoshere depth range across the Arctic region.

The seismic and thermal models map the deep lithospheric boundaries of tectonic blocks with different properties and different age-including cratons, Phanerozoic continents, locations of intraplate volcanism, and old and young oceans-and offer new insights into the dynamics and evolution of the Arctic lithosphere.

This work was supported by the Science Foundation Ireland (grants 13/CDA/2192 and 09/RFP/GEO2550) and the Natural Sciences and Engineering Research Council (NSERC) of Canada (Postdoctoral Fellowship to AS). The research leading to these results has received funding from the People Programme (Marie Curie Actions) of the European Union's H2020-MSCA-IF-2014 programme under REA grant agreement $n^{\circ}$ 657357 (grant awarded to JF). VP acknowledges funding from Swedish Research Council and CALE sponsors. All figures were generated using Generic Mapping Tools (GMT, Wessel \& Smith 1995).

\section{References}

Afonso, J.C., Ranalli, G. \& Fernàndez, M. 2005. Thermal expansivity and elastic properties of the lithospheric mantle: results from mineral physics of composites. Phys. Earth Planet. Int., 149, 279-306.

Afonso, J. C., Fernàndez, M., Ranalli, G., Griffin W. L. \& Connolly, J. A. D. 2008. Integrated geophysicalpetrological modeling of the lithosphere and sublithospheric upper mantle: Methodology and applications, Geochem. Geophys. Geosyst., 9, Q05008, doi:10.1029/2007GC001834.

Afonso, J. C. \& Zlotnik, S. 2011. The subductability of the continental lithosphere: the before and after story. in D. Brown \& P.D. Ryan (eds.), Arc-continent collision, Frontiers in Earth Sciences, Springer, 53-86.

Afonso, J.C., Fullea, J., Griffin, W.L., Yang, Y., Jones, A.G., Connolly, J. A. D. \& O'Reilly, S.Y. 2013. 3-D multiobservable probabilistic inversion for the compositional and thermal structure of the lithosphere and upper mantle. I: a priori petrological information and geophysical observables. Journal of Geophysical Research: Solid Earth, 118(5), 2586-2617.

Altenbernd, T., Jokat, W., Heyde, I. \& Damm, V. 2016. Insights into the crustal structure of the transition between Nares Strait and Baffin Bay. Tectonophysics, doi:10.1016/j.tecto.2016.04.001. 
Amaru, M.L. 2007. Global travel time tomography with 3-D reference models. Ph.D. Thesis. Utrecht University. Geologica Ultraiectina, 274. http://igitur-archive.library.uu.nl/dissertations/20070202-201924/index.htm

Artemieva, I.M. 2006. Global $1 \times 1$ thermal model TC1 for the continental lithosphere: implications for lithosphere secular evolution. Tectonophysics, 416(1), 245-277.

Artemieva, I. M., Thybo, H. \& Kaban, M. K. 2006. Deep Europe today: geophysical synthesis of the upper mantle structure and lithospheric processes over 3.5 Ga. Geological Society, London, Memoirs, 32, 11-41.

Auer, L., Boschi, L., Becker, T.W., Nissen-Meyer, T. \& Giardini, D. 2014. Savani: A variable resolution whole-mantle model of anisotropic shear velocity variations based on multiple data sets. Journal of Geophysical Research: Solid Earth, 119(4), 3006-3034.

Bartzsch, S., Lebedev, S. \& Meier, T. 2011. Resolving the lithosphere-asthenosphere boundary with seismic Rayleigh waves. Geophysical Journal International, 186(3), 1152-1164.

Bassin, C., Laske, G. \& Masters, G. 2000. The Current Limits of Resolution for Surface Wave Tomography in North America. Eos, 81.

Becker, T. W., Conrad, C. P., Schaeffer, A. J. \& Lebedev, S. 2014. Origin of azimuthal seismic anisotropy in oceanic plates and mantle. Earth Planet. Sci. Lett., 401, 236-250.

Bijwaard, H. \& Spakman, W., 2000. Non-linear global P-wave tomography by iterated linearized inversion. Geophys. J. Int., 141, 71-82.

Bruneton, M., Pedersen, H., Farra, V., Arndt, N., Vacher, P., Achauer, U., Alinaghi, A., Ansorge, J., Bock, G., Friederich, W., Grad, M., Guterch, A., Heikkinen, P., Hjelt, S.-E., Hyvoenen, T., Ikonen, J.-P., Kissling, E., Komminaho, K., Korja, A., Kozlovskaya, E., Nevky, M., Paulssen, H., Pavlenkova, N., Plomerova, J., Raita, T., Riznichenko, O., Roberts, R., Sandoval, S., Sanina, I., Sharov, N., Shomali, Z., Tiikainen, J., Wielandt, E., Wilegalla, K., Yliniemi, J. \& Yurov, Y. 2004. Complex lithospheric structure under the Central Baltic Shield from surface wave tomography. J. geophys. Res., 109(B10), doi:10.1029/2003JB002947.

Burgos, G., Montagner, J.P., Beucler, E., Capdeville, Y., Mocquet, A. \& Drilleau, M. 2014. Oceanic lithosphere-asthenosphere boundary from surface wave dispersion data. Journal of Geophysical Research: Solid Earth, 119(2), 1079-1093.

Burke, K. \& Dewey, J.F. 1973. Plume-generated triple junctions: key indicators in applying plate tectonics to old rocks. The Journal of Geology, 406-433.

Burov, E. B. \& Watts, A. B. 2006. The long-term strength of continental lithosphere: "jelly sandwich" or "crème brûlée"?. GSA today, 16(1), 4.

Cammarano, F., Goes, S., Vacher, P. \& Giardini, D. 2003. Inferring upper-mantle temperatures from seismic velocities. Physics of the Earth and Planetary Interiors, 138(3), 197-222. 
Chian, D., Jackson, H.R., Hutchinson, D.R., Shimeld, J.W., Oakey, G.N., Lebedeva-Ivanova, N., Li, Q., Saltus, R.W. \& Mosher, D.C. 2016. Distribution of crustal types in Canada Basin, Arctic Ocean. Tectonophysics, http://dx.doi.org/10.1016/j.tecto.2016.01.038.

Coakley, B.J. \& Cochran, J.R. 1998. Gravity evidence of very thin crust at the Gakkel Ridge (Arctic Ocean). Earth and Planetary Science Letters, 162(1), 81-95.

Connolly, J.A.D. 2005. Computation of phase equilibria by linear programming: a tool for geodynamic modeling and its application to subduction zone decarbonation. Earth and Planetary Science Letters, 236(1), 524-541.

Connolly, J.A.D. \& Kerrick, D. 2002. Metamorphic controls on seismic velocity of subducted oceanic crust at 100-250 km depth. Earth and Planetary Science Letters, 204(1-2), 61-74.

Davis, E.E. \& Lister, C.R.B. 1974. Fundamentals of ridge crest topography. Earth and Planetary Science Letters, 21(4), 405-413.

Dawes, P. R., Frisch, T. \& Christie, R. L. 1982. The Proterozoic Thule Basin of Greenland and Ellesmere Island: Importance to the Nares Strait debate. In: Dawes, P. R. \& Kerr, J. W. (eds) Nares Strait and the Drift of Greenland: A Conflict in Plate Tectonics. Meddelelser om Grønland Geosciences, 8-1982, 89-104.

Dawes, P. R. \& Kerr, J. W. (eds) 1982. Nares Strait and the Drift of Greenland: A Conflict in Plate Tectonics. Meddelelser om Grønland Geosciences, 8-1982.

Debayle, E., Dubuffet, F. \& Durand, S. 2016. An automatically updated S-wave model of the upper mantle and the depth extent of azimuthal anisotropy, Geophys. Res. Lett., 43, doi:10.1002/2015GL067329.

Deschamps, P., Trampert, J. \& Snieder, R. 2002. Anomalies of temperature and iron in the uppermost mantle inferred from gravity data and tomographic models. Physics of the Earth and Planetary Interiors, 129, 245-264.

Dobretsov, N.L., Vernikovsky, V.A., Karyakin, Y.V., Korago, E.A. \& Simonov, V.A. 2013. MesozoicCenozoic volcanism and geodynamic events in the Central and Eastern Arctic. Russian Geology and Geophysics, 54(8), 874-887.

Embry, A. \& Beauchamp, B., 2008. Sverdrup basin. Sedimentary basins of the world, 5, 451-471.

Foley, S. F. 2008. Rejuvenation and erosion of the cratonic lithosphere, Nature Geosc., 1, 503-510.

French, S., Lekic, V. \& Romanowicz, B. 2013. Waveform tomography reveals channeled flow at the base of the oceanic asthenosphere. Science, 342(6155), 227-30.

Fullea, J., Afonso, J.C., Connolly, J.A.D., Fernández, M., García-Castellanos, D. \& Zeyen, H. 2009. LitMod3D: An interactive 3-D software to model the thermal, compositional, density, 
seismological, and rheological structure of the lithosphere and sublithospheric upper mantle. Geochemistry, Geophysics, Geosystems, 10(8), Q08019, doi:10.1029/2009GC002391.

Fullea, J., Lebedev, S., Agius, M.R., Jones, A.G. \& Afonso, J.C. 2012. Lithospheric structure in the Baikalcentral Mongolia region from integrated geophysical-petrological inversion of surface-wave data and topographic elevation. Geochemistry, Geophysics, Geosystems, 13(8), Q0AK09, doi:10.1029/2012GC004138.

Gaina, C., Medvedev, S., Torsvik, T.H., Koulakov, I. \& Werner, S.C. 2014. 4D Arctic: a glimpse into the structure and evolution of the arctic in the light of new geophysical maps, plate tectonics and tomographic models. Surveys in Geophysics, 35(5), 1095-1122.

Ganerød, M., Smethurst, M.A., Torsvik, T.H., Prestvik, T., Rousse, S., McKenna, C., Van Hinsbergen, D.J.J. \& Hendriks, B.W.H. 2010. The North Atlantic Igneous Province reconstructed and its relation to the plume generation zone: the Antrim lava group revisited. Geophysical Journal International, 182(1), 183-202.

Goes, S., Govers, R. \& Vacher, P. 2000. Shallow mantle temperatures under Europe from P and S wave tomography. J. Geophys. Res., 105, 11153-11169.

Griffin, W.L., O'Reilly, S.Y., Afonso, J.C. \& Begg, G. 2009. The composition and evolution of lithospheric mantle: a re-evaluation and its tectonic implications. Journal of Petrology, 50(7), 1185-1204.

Herron, E.M., Dewey, J.F. \& Pitman, W.C. 1974. Plate tectonics model for the evolution of the Arctic. Geology, 2(8), 377-380.

Jakobsson, M., Mayer, L., Coakley, B., Dowdeswell, J.A., Forbes, S., Fridman, B., Hodnesdal, H., Noormets, R., Pedersen, R., Rebesco, M., Schenke, H.W., Zarayskaya, Y., Accettella, D., Armstrong, A., Anderson, R. M., Bienhoff, P., Camerlenghi, A., Church, I., Edwards, M., Gardner, J. V., Hall, J. K., Hell, B., Hestvik, O., Kristoffersen, Y., Marcussen, C., Mohammad, R., Mosher, D., Nghiem, S. V., Pedrosa, M. T., Travaglini, P. G. \& Weatherall, P. 2012. The international bathymetric chart of the Arctic Ocean (IBCAO) version 3.0. Geophysical Research Letters, 39(12), L12609, DOI: 10.1029/2012GL052219.

Jordan, T. H. 1975. The continental tectosphere. Rev. Geophys., 13, 1- 12.

Jordan, T. H. 1988. Structure and formation of the continental tectosphere. J. Petrol., 1, $11-37$.

Karato, S.i. 1993. Importance of anelasticity in the interpretation of seismic tomography. Geophys. Res. Lett., 20, 1623-1626.

Katz, R. F., Spiegelman, M. \& Langmuir, C. H. 2003. A new parameterization of hydrous mantle melting. Geochemistry, Geophysics, Geosystems, 4(9).

Khan, A., Boschi, L. \& Connolly, J.A.D. 2009. On mantle chemical and thermal heterogeneities and anisotropy as mapped by inversion of global surface wave data. Journal of Geophysical Research: Solid Earth, 114(B9). 
Khan, A., Boschi, L. \& Connolly, J. A. D. 2011. Mapping the Earth's thermochemical and anisotropic structure using global surface wave data. Journal of Geophysical Research: Solid Earth, 116, B01301.

Lawver L.A. \& Müller R.D. 1994. Iceland hotspot track. Geology, 22(4), 311-314.

Lawver, L.A., Grantz, A. \& Gahagan, L.M. 2002. Plate kinematic evolution of the present Arctic region since the Ordovician. Special Papers-Geological Society of America, 333-358.

Lebedev, S., Nolet, G. \& Van Der Hilst, R.D. 1997. The upper mantle beneath the Philippine Sea region from waveform inversions. Geophysical research letters, 24(15), 1851-1854.

Lebedev, S. \& Nolet, G. 2003. Upper mantle beneath Southeast Asia from S velocity tomography. Journal of Geophysical Research: Solid Earth, 108(B1), 2048, doi:10.1029/2000JB000073.

Lebedev, S., Nolet, G., Meier, T. \& van der Hilst, R. D. 2005. Automated multimode inversion of surface and S waveforms, Geophys. J. Int., 162, 951-964.

Lebedev, S., Meier, T. \& van der Hilst, R.D. 2006. Asthenospheric flow and origin of volcanism in the Baikal Rift area. Earth and Planetary Science Letters, 249(3), 415-424.

Lebedev, S. \& van der Hilst, R. D. 2008. Global upper-mantle tomography with the automated multimode inversion of surface and S-wave forms. Geophys. J. Int., 173, 505-518.

Lebedev, S., Boonen, J. \& Trampert, J. 2009. Seismic structure of Precambrian lithosphere: New constraints from broad-band surface-wave dispersion. Lithos, 109, 96-111.

Lebedev, S., Adam, J.M.C. \& Meier, T. 2013. Mapping the Moho with seismic surface waves: A review, resolution analysis, and recommended inversion strategies. Tectonophysics, 609, 377-394.

Legendre, C. P., Meier, T., Lebedev, S., Friederich, W. \& Viereck-Götte, L. 2012. A shear wave velocity model of the European upper mantle from automated inversion of seismic shear and surface waveforms. Geophys. J. Int., 191, 282-304.

Levshin, A. L., Schweitzer, J., Weidle, C., Shapiro, N. M., \& Ritzwoller, M. H. 2007. Surface wave tomography of the Barents Sea and surrounding regions. Geophys. J. Int., 170, 441-459.

Maggi, A., Debayle, E., Priestley, K. \& Barruol, G. 2006. Multimode surface waveform tomography of the Pacific Ocean: a closer look at the lithospheric cooling signature. Geophysical Journal International, 166(3), 1384-1397.

McDonough, W.F. \& Sun, S.-S. 1995. The composition of the Earth. Chem. Geol., 120, 223-253.

Meier, T., R. Soomro, S. Lebedev, C. Weidle, L. Viereck, J. Behrmann, L. Cristiano, R. Hanemann. Mesozoic and Cenozoic Evolution of the Central European Lithosphere. Tectonophysics, in revision, 2016. 
Midwinter, D., Hadlari, T., Davis, W.J., Dewing, K. \& Arnott, R.W.C. 2016. Dual provenance signatures of the Triassic northern Laurentian margin from detrital-zircon $\mathrm{U} ? \mathrm{~Pb}$ and $\mathrm{Hf}$ ? isotope analysis of Triassic-Jurassic strata in the Sverdrup Basin, Lithosphere, doi:10.1130/L517.1.

Mihalffy, P., Steinberger, B. \& Schmeling, H. 2008. The effect of the large-scale mantle flow field on the Iceland hotspot track. Tectonophysics, 447(1), 5-18.

Minster, J.B. \& Anderson, D.L. 1981. A model of dislocation-controlled rheology for the mantle. Phil. Trans. R. Soc. A., 299, 319-356

Morgan, W.J. \& Morgan, J.P. 2005. Volcanism due to horizontal sublithospheric flow, 4th "Deep Earth: Theory, Experiment and Observation" Research Conference, Lithosphere-Asthenosphere Interaction, Frejus, France.

Pedersen, H., Debayle, E. \& Maupin, V. 2013. Strong lateral variations of lithospheric mantle beneath cratons - Example from the Baltic Shield. Earth and Planetary Science Letters, 383, 164 - 172.

Petrov, O., Morozov, A., Shokalsky, S., Kashubin, S., Artemieva, I.M., Sobolev, N., Petrov, E., Ernst, R.E., Sergeev, S. \& Smelror, M. 2016. Crustal structure and tectonic model of the Arctic region. EarthScience Reviews, 154, 29-71.

Petrunin, A.G., Rogozhina, I., Vaughan, A.P.M., Kukkonen, I.T., Kaban, M.K., Koulakov, I. \& Thomas, M. 2013. Heat flux variations beneath central Greenland's ice due to anomalously thin lithosphere. Nature Geoscience, 6(9), 746-750.

Poudjom Djomani , Y. H., O'Reilly, S. Y., Griffin, W.L. \& Morgan, P. 2001. The density structure of subcontinental lithosphere through time. Earth Planet. Sc. Lett., 184, 605-621.

Pease, V., Drachev, S., Stephenson, R. \& Zhang, X. 2014. Arctic lithosphere-A review. Tectonophysics, $628,1-25$.

Renne, P.R. \& Basu, A.R. 1991. Rapid eruption of the Siberian Traps flood basalts at the Permo-Triassic boundary. Science, 253(5016), 176-179.

Rickers, F., Fichtner, A. \& Trampert, J. 2013. The Iceland-Jan Mayen plume system and its impact on mantle dynamics in the North Atlantic region: Evidence from full-waveform inversion. Earth and Planetary Science Letters, 367, $39-51$.

Ritsema, J., Deuss, A., van Heijst, H. J. \& Woodhouse, J. H. 2011. S40RTS: a degree-40 shear-velocity model for the mantle from new Rayleigh wave dispersion, teleseismic traveltime and normalmode splitting function measurements. Geophys. J. Int., 184, 1223-1236.

Saalmann, K., Tessensohn, F., Piepjohn, K., Von Gosen, W. \& Mayr, U. 2005. Structure of Palaeogene sediments in east Ellesmere Island: constraints on Eurekan tectonic evolution and implications for the Nares Strait problem. Tectonophysics, 406(1), 81-113. 
Saumur, B.M., Dewing, K. \& Williamson, M.C., 2016. Architecture of the Canadian portion of the High Arctic Large Igneous Province and implications for magmatic Ni-Cu potential. Canadian Journal of Earth Sciences, 53(5), 528-542.

Schaeffer, A. J. \& Lebedev, S., 2013. Global shear-speed structure of the upper mantle and transition zone. Geophys. J. Int., 194, 417-449.

Schaeffer, A. \& Lebedev, S. 2014. Imaging the North American continent using waveform inversion of global and USArray data, Earth Planet. Sc. Lett., 402, 26-41.

Schaeffer, A. J. \& Lebedev, S. 2015. Global heterogeneity of the lithosphere and underlying mantle: A seismological appraisal based on multimode surface-wave dispersion analysis, shear-velocity tomography, and tectonic regionalization. In: "The Earth's Heterogeneous Mantle, "A. Khan and F. Deschamps (eds.), Springer Geophysics, doi:10.1007/978-3-319-15627-9_1, 3-46.

Schaeffer, A. J., Lebedev, S. \& Becker, T. W. 2016a. Azimuthal seismic anisotropy in the Earth's upper mantle and the thickness of tectonic plates, Geophys. J. Int., in revision.

Schaeffer, A. J., Lebedev, S. \& Gaina, C., 2016b. Structure of the Circum-Arctic lithosphere and asthenosphere imaged using multimode waveform tomography, Tectonophysics, Invited Research Paper, being submitted shortly.

Schiffer, C., Tegner, C., Schaeffer, A. J., Pease, V. \& Nielsen, S. B. 2016. The High Arctic geopotential stress field and its implications for the geodynamic evolution. This volume.

Schlindwein, V., Müller, C. \& Jokat, W. 2007. Microseismicity of the ultraslow-spreading Gakkel ridge, Arctic Ocean: a pilot study. Geophysical Journal International, 169(1), 100-112.

Schmidt-Aursch, M. C. \& Jokat, W. 2016. 3D gravity modelling reveals off-axis crustal thickness variations along the western Gakkel Ridge (Arctic Ocean), Tectonophysics, in press.

Schutt, D.L. \& Lesher, C.E. 2006. Effects of melt depletion on the density and seismic velocity of garnet and spinel Iherzolite. Journal of Geophysical Research, 111, doi:10.1029/2003JB002950.

Shapiro, N.M. \& Ritzwoller, M.H. 2002. Monte-Carlo inversion for a global shear-velocity model of the crust and upper mantle. Geophysical Journal International, 151(1), 88-105.

Sobolev, S.V., Zeyen, H., Stoll, G., Werling, F., Altherr, R. \& Fuchs, K. 1996. Upper mantle temperatures from teleseismic tomography of French Massif Central including effects of composition, mineral reactions, anharmonicity, anelasticity and partial melt. Earth and Planetary Science Letters, 139(1), 147-163.

Sobolev, S.V., Sobolev, A.V., Kuzmin, D.V., Krivolutskaya, N.A., Petrunin, A.G., Arndt, N.T., Radko, V.A. \& Vasiliev, Y.R. 2011. Linking mantle plumes, large igneous provinces and environmental catastrophes. Nature, 477(7364), 312-316.

St-Onge, M.R., Van Gool, J.A., Garde, A.A. \& Scott, D.J. 2009. Correlation of Archaean and Palaeoproterozoic units between northeastern Canada and western Greenland: constraining the 
pre-collisional upper plate accretionary history of the Trans-Hudson orogen. Geological Society, London, Special Publications, 318(1), 193-235.

Stein, C. A. \& Stein, S. 1992. A model for the global variation in oceanic depth and heat flow with lithospheric age. Nature, 359(6391), 123-129.

Stein, C.A. \& Stein, S. 2015. Are large oceanic depth anomalies caused by thermal perturbations?, In: Foulger, G.R., Lustrino, M., and King, S.D., eds., The Interdisciplinary Earth: A Volume in Honor of Don L. Anderson: Geological Society of America Special Paper 514 and American Geophysical Union Special Publication 71, doi:10.1130/2015.2514(12).

Stephenson, R.A., Embry, A.F., Nakiboglu, S.M. \& Hastaoglu, M.A. 1987. Rift-initiated Permian to Early Cretaceous subsidence of the Sverdrup basin. In: Beaumont, C. \& Tankard, A. J. (Eds.), Sedimentary Basins and Basin-Forming Mechanisms. Canadian Society of Petroleum Geologists, Memoir 12, 213-231.

Tarduno, J. A. 1998. The high Arctic large igneous province. In: Third International Conference on Arctic Margins, 12-16.

Thiede, J. \& the shipboard scientific party, 2002. Cruise Report: AMORE2001, Rep. Polar Mar. Res., 421, 397 pp.

Thompson, R.N. \& Gibson, S.A. 1991. Subcontinental mantle plumes, hotspots and pre-existing thinspots. Journal of the Geological Society, 148(6), 973-977.

Torsvik, T.H., Amundsen, H.E., Trønnes, R.G., Doubrovine, P.V., Gaina, C., Kusznir, N.J., Steinberger, B., Corfu, F., Ashwal, L.D., Griffin, W.L. \& Werner, S.C. 2015. Continental crust beneath southeast Iceland. Proceedings of the National Academy of Sciences, 112(15), E1818-E1827.

Wegener, A. 1929. The origin of continents and oceans (4th ed.) New York, Dover (1966).

Weidle, C. \& Maupin, V. 2008. An upper-mantle S-wave velocity model for Northern Europe from Love and Rayleigh group velocities. Geophys. J. Int., 175, 1154-1168.

White, N. \& Lovell, B. 1997. Measuring the pulse of a plume with the sedimentary record. Nature, 387(6636), 888-891.

Wilson, J.T. 1963. Hypothesis of earth's behaviour. Nature, 198, 925-929.

Yakovlev, A.V., Bushenkova, N.A., Koulakov, I.Y. \& Dobretsov, N.L. 2012. Structure of the upper mantle in the Circum-Arctic region from regional seismic tomography. Russian Geology and Geophysics, 53(10), 963-971. 
Table 1: Bulk mantle compositions used in this work from xenoliths suites and peridotite massifs.

843

\begin{tabular}{|l|l|l|l|c|}
\hline & $\begin{array}{c}\text { 1) Av. } \\
\text { Phanerozoic } \\
(w t \%)^{\mathrm{a}}\end{array}$ & $\begin{array}{c}\text { 2) Average } \\
\text { Proterozoic } \\
(w t \%)^{\mathrm{a}}\end{array}$ & $\begin{array}{c}\text { 3) Average } \\
\text { Archean } \\
(w+\%)^{\mathrm{a}}\end{array}$ & $\begin{array}{c}\text { 4) PUM M\&S95 } \\
(w \mathrm{w} \%)^{\mathrm{b}}\end{array}$ \\
\hline $\mathrm{SiO}_{2}$ & 44.5 & 44.6 & 45.7 & 45 \\
\hline $\mathrm{TiO}_{2}$ & 0.14 & 0.07 & 0.04 & 0.201 \\
\hline $\mathrm{Al}_{2} \mathrm{O}_{3}$ & 3.5 & 1.9 & 0.99 & 4.45 \\
\hline $\mathrm{Cr}_{2} \mathrm{O}_{3}$ & 0.4 & 0.4 & 0.28 & 0.384 \\
\hline $\mathrm{FeO}$ & 8.0 & 7.9 & 6.4 & 8.05 \\
\hline $\mathrm{MnO}$ & 0.13 & 0.12 & 0.11 & 0.135 \\
\hline $\mathrm{MgO}$ & 39.8 & 42.6 & 45.5 & 37.8 \\
\hline $\mathrm{CaO}$ & 3.1 & 1.7 & 0.59 & 3.55 \\
\hline $\mathrm{Na}{ }_{2} \mathrm{O}$ & 0.24 & 0.12 & 0.07 & 0.36 \\
\hline $\mathrm{NiO}$ & 0.26 & 0.26 & 0.3 & - \\
\hline $\mathrm{Mg \#}$ & 89.9 & 90.6 & 92.7 & 89.3 \\
\hline
\end{tabular}

844

${ }^{a}$ Global average taken from Griffin et al.(2009).

$845{ }^{b}$ PUM stands for Primitive Upper Mantle, M\&S95 refers to McDonough and Sun (1995).

846

847

848

849

850

851

852 
Table 2: Assumed geophysical properties of different crustal layers.

\begin{tabular}{|l|l|l|l|}
\hline Layer & Density $\left(\mathrm{kg} / \mathrm{m}^{3}\right)$ & Heat & Thermal \\
& & production & conductivity \\
& & $\left(\mathrm{W} / \mathrm{m}^{3}\right)$ & $(\mathrm{W} / \mathrm{m} \mathbf{K})$ \\
\hline Oceanic sediments & 2200 & $1.210^{-6}$ & 3 \\
\hline Oceanic crust & & & \\
\hline Continental Crust & 2920 & $110^{-7}$ & 2.1 \\
\hline Beaufort Sea sediments & & & \\
\hline Beaufort Sea crust & 2850 & $0.710^{-6}$ & 2.5 \\
\hline & & $210^{-6}$ & 3 \\
\hline & 2950 & $110^{-7}$ & 2.1 \\
\hline
\end{tabular}

\section{Figure captions}

Fig. 1. Topographic map of the Arctic region. Ridges on the High-Arctic seafloor are shown as green hatched areas, locations of intraplate volcanism - as red hatched areas (Gaina et al. 2014; Schiffer et al. 2016). AB, Amundsen Basin; AR, Alpha Ridge; BI, Baffin Island; BR, Brooks Range; BS, Baltic Shield; CB, Chukchi Borderlands; CDF, Cordilleran Deformation Front; DI, Devon Island; EI, Ellesmere Island; FJL, Franz Josef Land; HB, Hudson Bay; LR, Lomonosov Ridge; LS, Laptev Sea; MAR, Mid-Atlantic Ridge; MB,

864 Makarov Basin; MR, Mendeleev Ridge; NB, Nansen Basin; Nvl, Novosibirsk Islands; NZ, Novaya Zemlya; SB, Sverdrup Basin; SZ, Severnaya Zemlya; UM, Ural Mountains; VF, Verkhoyansk Fold Belt.

Fig. 2. Type profiles of temperature and density beneath an old ocean with a 100-km thick lithosphere, a 868 young ocean with a $60-\mathrm{km}$ thick lithosphere and a layer of sediments atop the crystalline crust, and a 869 Phanerozoic continent with a 100-km thick lithosphere. 
872 Fig. 3. Broadband seismic stations (inverted triangles) and earthquakes (small squares) in and around 873 the Arctic region. These sources and stations were used in the waveform tomography of the Arctic along 874 with our global set of stations and earthquakes (Schaeffer \& Lebedev 2014; Schaeffer et al. 2016b).

875

876

877

878

879

880

881

882

883

884

885

886

887

888

889

890

891

892

893

894

895

896

897

898

899

900

901

Fig. 4. Map views of our tomographic model at four depths in the shallow upper mantle. The reference values of the vertically-polarized S-wave speed in the mantle are: $4.46 \mathrm{~km} / \mathrm{s}$ at $36 \mathrm{~km}$ depth, $4.42 \mathrm{~km} / \mathrm{s}$ at $56 \mathrm{~km}$ depth, and $4.38 \mathrm{~km} / \mathrm{s}$ at 80 and $110 \mathrm{~km}$ depths. Where the depths shown fall within the crust, the reference values are those of CRUST2.0 (Bassin et al., 2000; http://igppweb.ucsd.edu/ gabi/crust2.html), smoothed at its block boundaries. The reference values and deviations from them are at the reference period $50 \mathrm{~s}$.

Fig. 5. Map views of our tomographic model at four depths in the deeper upper mantle. The reference values of the vertically-polarized S-wave speed in the mantle are: $4.39 \mathrm{~km} / \mathrm{s}$ at $150 \mathrm{~km}, 4.45 \mathrm{~km} / \mathrm{s}$ at 200 $\mathrm{km}, 4.62 \mathrm{~km} / \mathrm{s}$ at $250 \mathrm{~km}$, and $4.75 \mathrm{~km} / \mathrm{s}$ at $330 \mathrm{~km}$ depth. The reference values and deviations from them are at the reference period $50 \mathrm{~s}$.

Fig. 6. A comparison of vertically-polarized S-wave speed distributions at $100 \mathrm{~km}$ depth in the Arctic region according to different recent global tomographic models, AMISvArc (Schaeffer et al. 2016b); 3D2015_07Sv (Debayle et al. 2016); Savani (Auer et al. 2014); SEMum2 (French et al. 2013); S40RTS (Ritsema et al. 2011); CUB (Shapiro \& Ritzwoller 2002). Each model is plotted with respect to its own global mean at the depth.

Fig. 7. A comparison of vertically-polarized S-wave speed distributions at $150 \mathrm{~km}$ depth in the Arctic region according to different recent global tomographic models (as in Fig. 6). Each model is plotted with respect to its own global mean at the depth.

Fig. 8. Average temperature in the $80-150 \mathrm{~km}$ depth range, derived from our tomographic model.

Fig. 9. Estimated profiles of temperature and density beneath the central Canada Basin and the Beaufort Sea, compared with those of a Phanerozoic continent with a 100-km thick lithosphere. 
902 Fig. S1. A comparison of vertically-polarized S-wave speed distributions at $50 \mathrm{~km}$ depth in the Arctic

903 region according to different recent global tomographic models (as in Fig. 6). Each model is plotted with 904 respect to its own global mean at the depth.

905

906 Fig. S2. A comparison of vertically-polarized S-wave speed distributions at $200 \mathrm{~km}$ depth in the Arctic

907 region according to different recent global tomographic models (as in Fig. 6). Each model is plotted with 908 respect to its own global mean at the depth.

909 


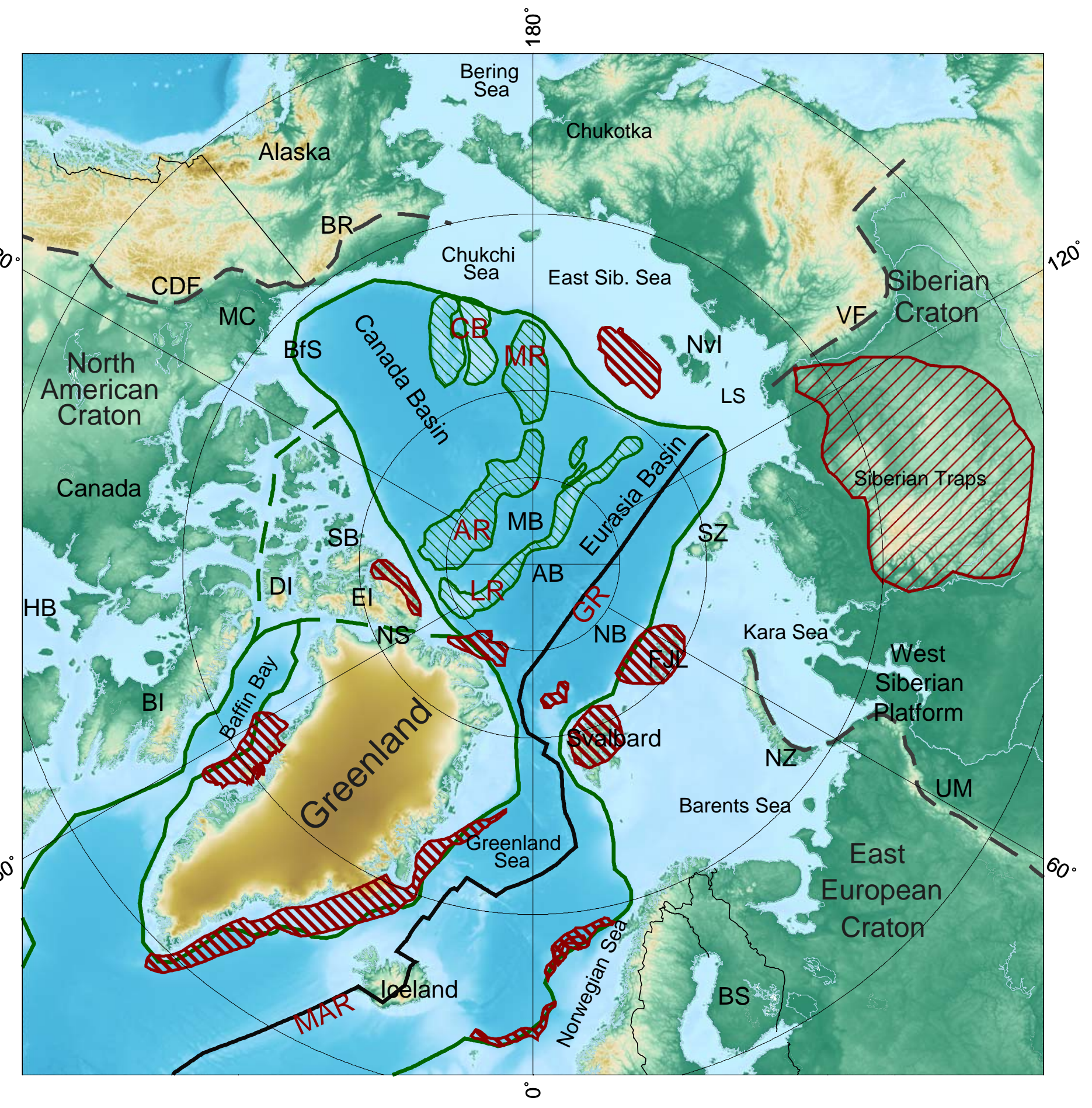




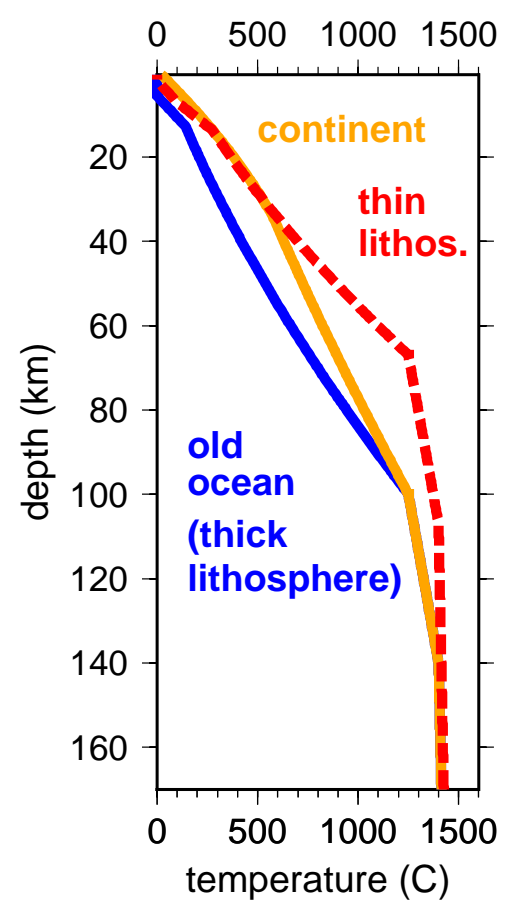

240028003200

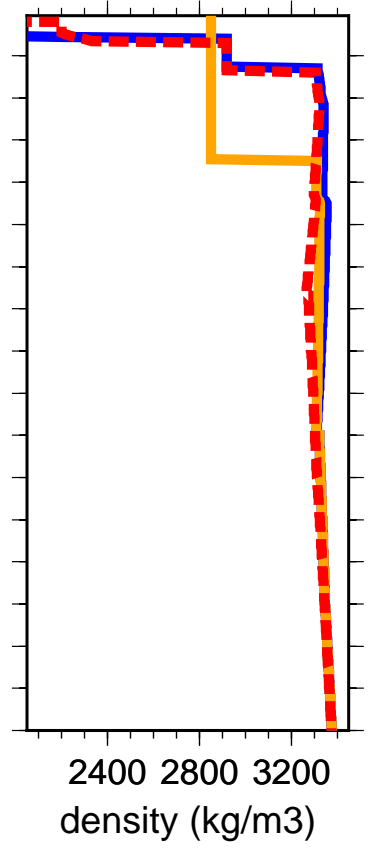




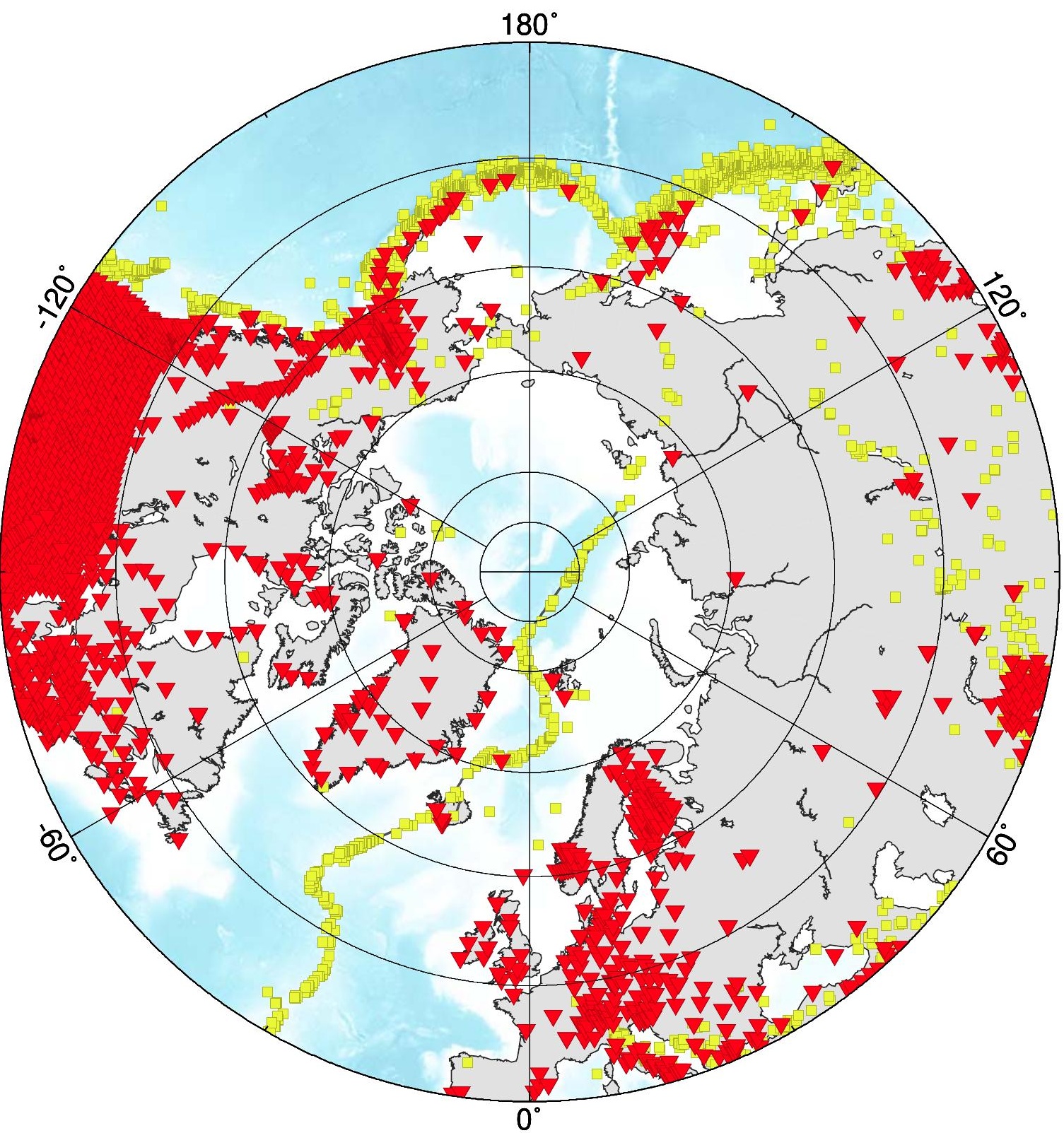



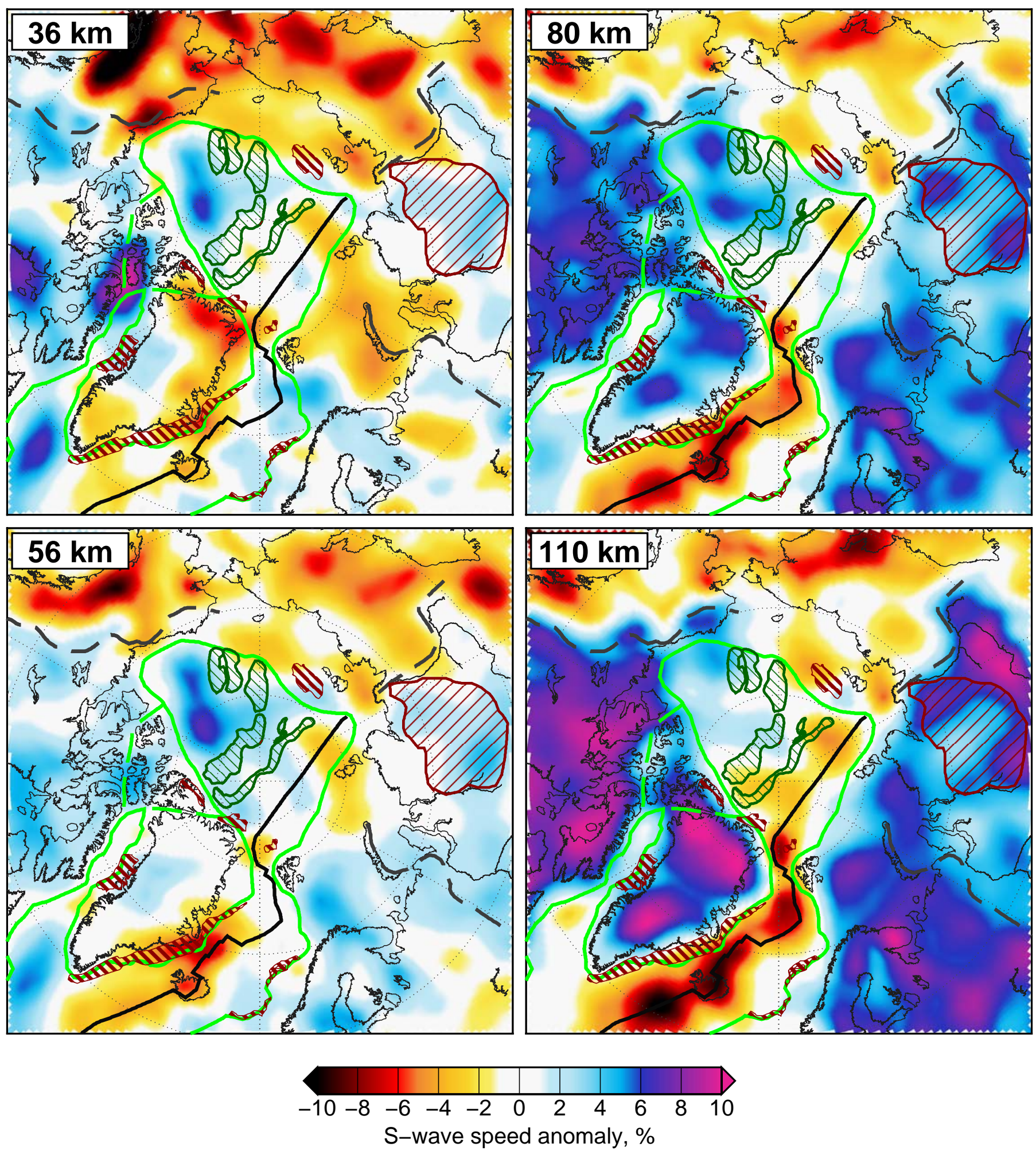

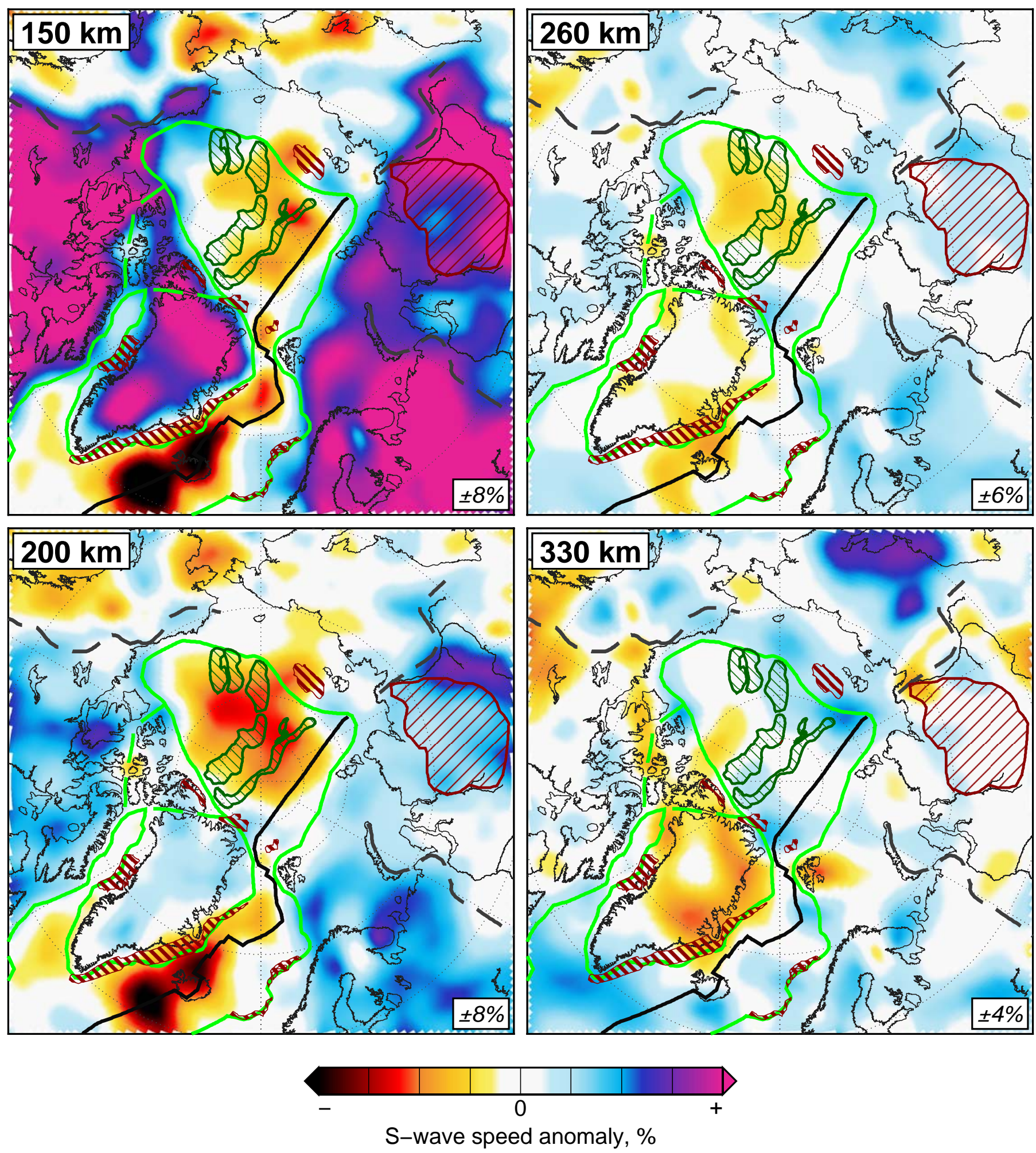

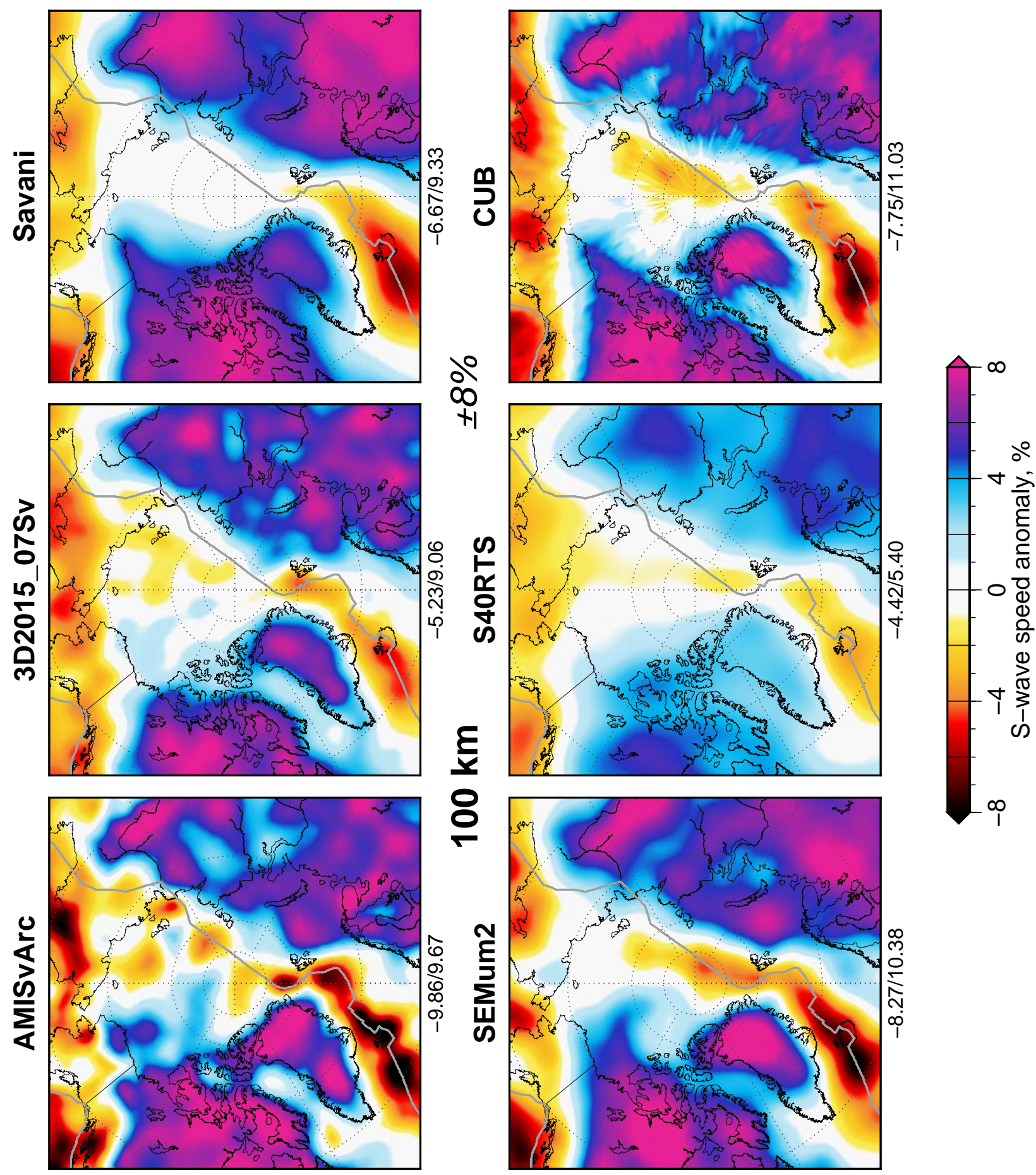


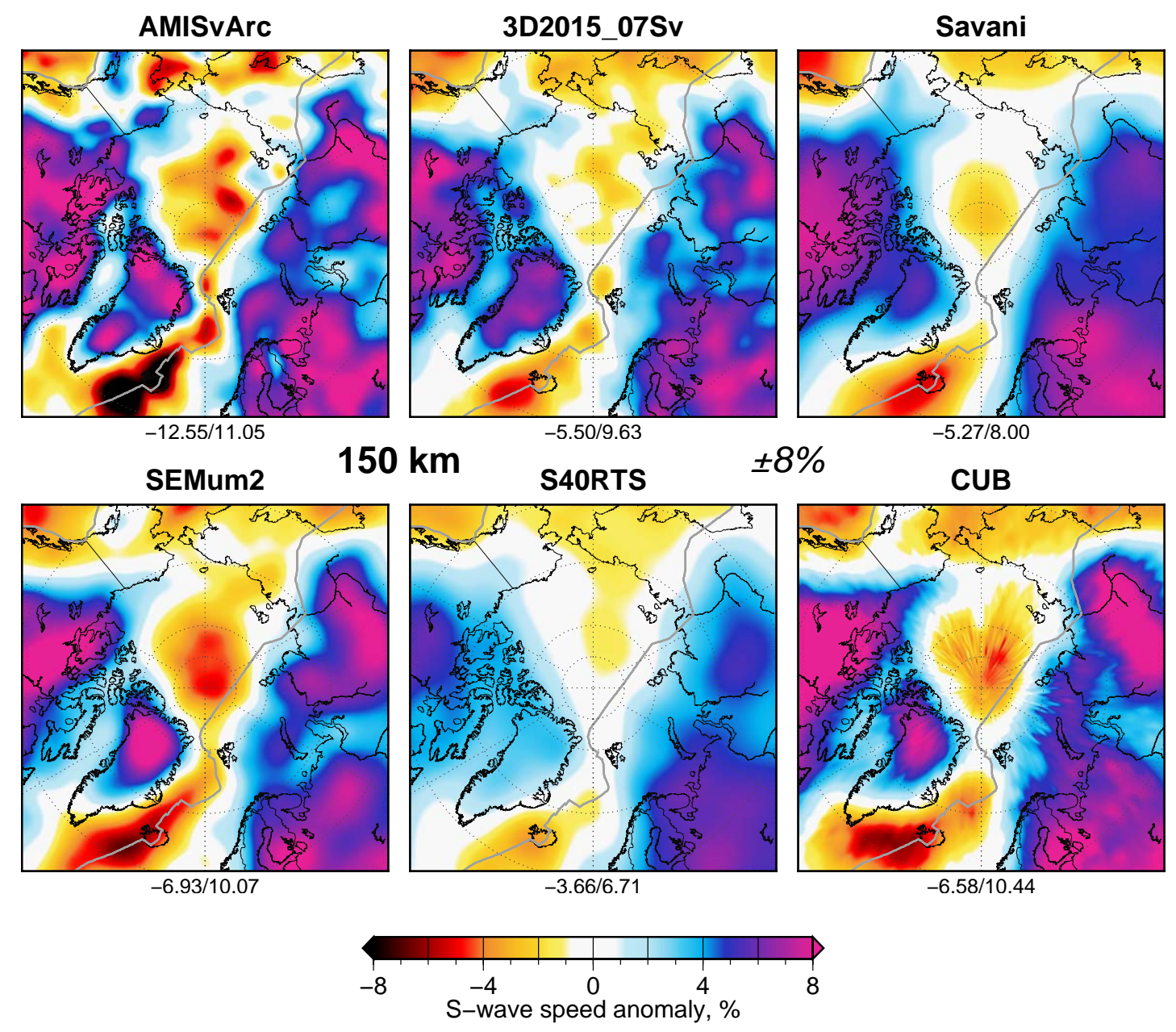


$80-150 \mathrm{~km}$

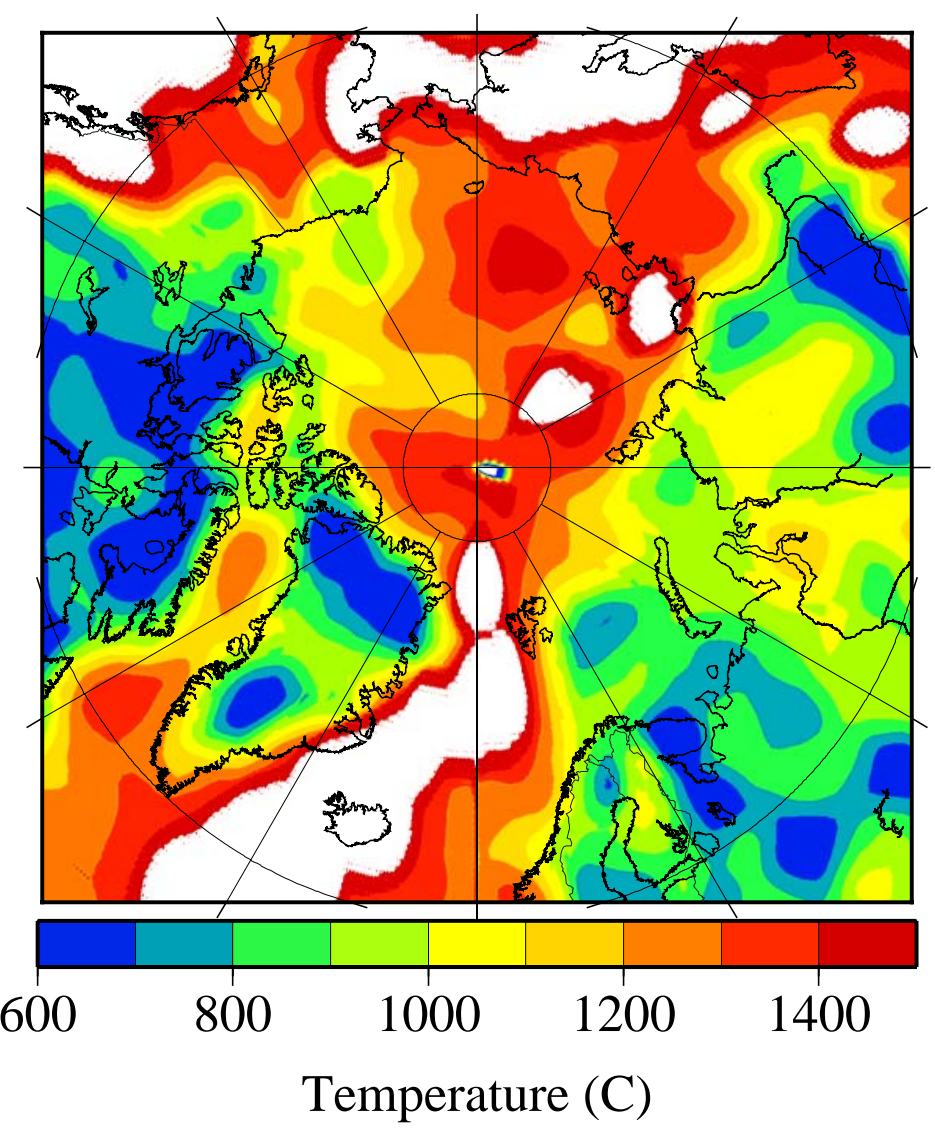


